\title{
Social Integration of 6-7 Year-Old Children in a Handball Initiation Group
}

\author{
Sburlan Irina ${ }^{1 *}$ \\ Rață Gloria² \\ ${ }^{1}$ NUPES Bucharest, 140, Constantin Noica. 060057, Romania

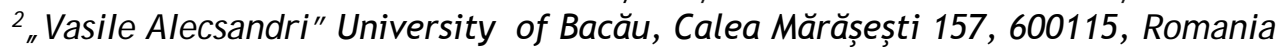

Keywords: children, group, cohesion, motion

\begin{abstract}
This study is observatory and aims at approaching the training process in 6-7-year-old children in handball in terms of socialization and its main objective is the creation of interpersonal relationships between the team players. By using the bibliographic study, sociometric test, analysis and interpretation of the data collected from 20 children (10 girls and 10 boys aged 6-7 years) who were enrolled in a training program in which the group formation was intended to be achieved, we managed to validate the hypothesis according to which if we use in a 6-7-year-old group of children exercises for teaching handball, the level of social integration is improved. The conclusion emphasizes that the results to the second test prove the efficiency of the means of a collective nature.
\end{abstract}

\section{Introduction}

Communication, socialization and the possibility of creating some interpersonal skills are needed for any individual in order to integrate into society. Physical education and sport are basic tools in the formation of these skills among both adults and children. Attitudes, skills, rules related to the sport activities can be transferred in any social sphere and adapted to it. In team sports, creating bonds within the group are absolutely necessary in order to improve the game.

This should be pursued and developed ever since the formation of the initiation groups, the binding of friendships, the formation of interconnections within the team being reflected in the game relations and by default in the quality of the game itself. The initiation activity in a sports discipline is a hard activity which requires a difficult and responsible job. The selection is active, ongoing and prospective.

Being an active, dynamic and continuous process, the selection is "twodimensional" and it is done vertically and horizontally. "In child beginners being only horizontally, the coach has the obligation to observe, to know the selection area and to check the availability for handball, namely the integration qualities and capabilities in collectives. The horizontal selection is active, the vertical one "aiming the promotion being rare, demanding and objective" (Balint, 2006, p. 11). It is

*E-mail: iris_sport@yahoo.com, gloria_rata50@yahu.com 
known that the maximum performance ability in girls and even in boys can be achieved after the age of 20; therefore a training cycle lasts between 8-10 years. At the same time, "the specialists' wish to conduct a more rational scheduling of the training content, methods and means has led to the athletes' need to schedule and program the sportsmen's training ” according to (Bota \& Bota, 1990). Besides the visible handball changes, such as the increase of the speed of the game and the players' characteristics, there are insights of the sports training science which influence the game evolution in time. Therefore, a step of major importance is the selection, namely "the material" which the activity starts with.

The age selection has decreased considerably in the last decade because "the school age is the best time for observing, learning, training and strengthening basic motor and sports skills necessary for educating the motor skills, being characterized by the greatest progress in terms of motor activity” (Rizescu, 2017a). Regarding the organizational forms, the handball training process is generally carried out in two forms "in schools, during the physical education lessons and in the handball sections of clubs and sports associations" (Rizescu, 2017b).

The study of the various bibliographic sources allows us to emphasize that the "golden age", as the young elementary school age is considered, is characterized by increases in height and weight, but also by assimilation of the motor skills.

"A skill is the result of learning, being a way of behavior which is shaped through practice, characterized by a number of series of specific features, but the synthesis performed on a cognitive, sensory motor or kinesthetic level may be considered the most important” (Epuran \& Stanescu, 2010, p. 269). The stage of basic training as directed training stage aims to enhance the skills and has as its main guideline to form the "team spirit” (Hantău, 2004), as a prerequisite in the preparation of team sports.

\section{Material and methods}

The study was conducted on an ethnically heterogeneous mixed handball group (10 girls and 10 boys), made up of 6-7 year-old children, the average age being 6.42 years (the standard deviation 0.51 years), belonging to "Grigorie Ghica Voievod/Prince Gregory Ghica” Secondary School in Sector 2, Bucharest.

The Children were selected at random from the preparatory and first grades at the beginning of the school year 2014-2015, training from October to June 2015, twice a week, on Mondays and Thursdays, for 90 minutes. The main training objectives in this category are the integration of children in a group, the specific and necessarily applicative basic motor skill training and the development of motor skills, with emphasis on the speed and coordination abilities, in addition to the shaping of personality.

Following these goals, we have checked the hypothesis according to which "if we use in a 6-7-year-old group of children exercises for teaching handball, the level of social integration is improved". In order to achieve the social and integration objectives, but also to know the level of the group cohesion, we used as a research method the questionnaire method, applying the Sociometric Test (taken 
from Colibaba-Evulet) on January $5^{\text {th }}$, 2015, three months after the beginning of the training, just to give children time to get to know each other and then after 6 months.

The test was conducted individually in writing and consisted of a questionnaire with 11 questions regarding their relationship with the others in the group. The first choice was given $+/-3$ points, the second $+/$ - 2 points and the last choice $+/-1$ point. For the questions with one answer only $+/-1$ point is given. After collecting the results, a socio-matrix was drawn and the number of choices or rejections for each child was calculated, the preferential status index for each group cohesion index to be determined after the second application of the questionnaire, if the drills performed had the desired effect, namely the improvement of group cohesion.

The working materials we used were: small handball balls, tennis balls, sticks, benches, ladder, flagpoles, sleeveless T-shirt shootouts, chairs, fences, gymnastics mattresses.

The sociometric test used by Lupu (2012) (a test taken by Colibaba-Evuleţ) targeted the answers to the following questions: Who are the first three of your colleagues you would like to go on a trip with?; Who would be the three colleagues you want to go on a trip with?; Who would be the first 3 colleagues with whom you would like to play on the field in an important game?; Who would be the three colleagues with whom you do not want to play on the field in an important game?; What is the ranking in value of the first 3 colleagues (including yourself); List in order 3 partners you may want to be in the team with; List in order 3 partners you do not want to work with; Which of your colleagues do you think would choose you?; Who would you count on in difficult situations? (3 colleagues); Who is your best partner from/outside the team?; Who is indifferent for you?” (Lupu, 2012, p. 295).

\section{Results and discussions}

The results recorded in the initial assessment can be found in Fig 1. Due to the large number of questions, there is the possibility for a child to be chosen several times in a questionnaire, which is why the number of points in the matrix box exceeds $+/-3$.

We can notice that, following the matrix interpretation, there are 4 children (SI, ED, RL, GR) 0 rejections, 3 of them being appreciated due to their behavior, being obedient, careful, receptive and constantly proving collegiality. The fourth, due to the number of absences is not very well known by the others, which is the reason why he did not receive any rejections, but the number of choices is very low with only 5. 


\begin{tabular}{|c|c|c|c|c|c|c|c|c|c|c|c|c|c|c|c|c|c|c|c|c|}
\hline & SI & RM & $\mathrm{AO}$ & ED & $\overline{\mathrm{AC}}$ & MR & $\mathrm{RA}$ & $\overline{D A}$ & DS & SD & $\overline{\mathrm{AC}}$ & SD & RT & II & $\mathrm{RD}$ & AT & $\mathrm{AI}$ & MO & BM & GR \\
\hline SI & & $\begin{array}{l}+5 \\
-3\end{array}$ & +7 & - & +2 & +2 & - & -3 & -1 & +2 & -2 & - & - & +1 & - & - & $\cdot$ & +8 & - & - \\
\hline RM & - & & - & +5 & - & - & +2 & +8 & - & +5 & - & +2 & - & - & - & +1 & - & -5 & - & - \\
\hline AO & +8 & -1 & & +2 & +3 & -2 & - & -2 & -3 & +2 & - & - & - & +5 & - & - & - & +5 & - & - \\
\hline ED & - & +2 & +1 & & - & - & +8 & +7 & +6 & - & - & - & +4 & - & - & - & - & - & - & - \\
\hline $\mathrm{AC}$ & +2 & - & - & - & & - & -2 & -5 & -5 & - & $\cdot$ & $\cdot$ & - & +7 & +1 & $\begin{array}{l}-2 \\
+2 \\
\end{array}$ & +3 & +9 & - & - \\
\hline $\mathbf{M R}$ & +3 & - & +2 & - & -3 & & - & -3 & - & -3 & +5 & -5 & - & +8 & - & - & +5 & - & - & $\cdot$ \\
\hline RA & - & +3 & - & +5 & - & - & & -3 & +5 & - & - & - & +7 & - & - & - & -3 & +4 & - & -1 \\
\hline DA & - & +1 & - & +8 & - & - & +9 & & -6 & -2 & +3 & - & +1 & - & - & +3 & - & - & - & +2 \\
\hline DS & - & -3 & - & - & - & - & +8 & - & & - & - & - & +12 & - & - & - & - & - & +2 & - \\
\hline SD & - & $\begin{array}{l}+3 \\
-1\end{array}$ & $\begin{array}{l}+4 \\
-3\end{array}$ & - & - & - & -2 & +3 & -3 & & - & -3 & - & -2 & - & +10 & +2 & +3 & +1 & - \\
\hline $\mathrm{AC}$ & +3 & - & - & - & - & +3 & +4 & -5 & -2 & +2 & & - & - & - & -3 & - & - & +4 & +2 & - \\
\hline SD & +1 & +2 & +10 & - & +4 & +5 & $\cdot$ & $\begin{array}{l}+3 \\
-3 \\
\end{array}$ & - & +4 & +1 & & - & - & - & - & $\cdot$ & -2 & - & - \\
\hline RT & +5 & +2 & - & +3 & +3 & - & +8 & -5 & -5 & - & - & - & & - & - & - & +1 & +3 & - & - \\
\hline II & +9 & - & +2 & - & - & +11 & - & -5 & - & -4 & - & -4 & - & & +1 & +2 & +1 & - & - & - \\
\hline $\mathrm{RD}$ & +3 & +2 & - & - & +6 & -4 & - & -6 & - & +11 & - & - & - & - & & - & - & +3 & - & +2 \\
\hline $\mathrm{AT}$ & +3 & -1 & - & - & +6 & +3 & +6 & -5 & $\begin{array}{l}-5 \\
\end{array}$ & -2 & - & - & - & +2 & - & & - & +4 & +2 & +3 \\
\hline AI & - & - & +2 & - & +7 & +1 & +4 & -3 & $\begin{array}{l}+2 \\
-3 \\
\end{array}$ & - & - & +5 & - & - & +1 & -2 & & +1 & -1 & - \\
\hline MO & - & - & - & +3 & +4 & - & +6 & $\begin{array}{l}+2 \\
-2 \\
\end{array}$ & -5 & +3 & - & +1 & +3 & -2 & -1 & +2 & +1 & & - & +1 \\
\hline BM & - & - & - & - & +9 & - & - & $\begin{array}{l}+3 \\
-2 \\
\end{array}$ & -2 & -1 & +3 & +6 & - & - & +2 & +2 & +3 & - & & $\cdot$ \\
\hline GR & $\cdot$ & -5 & +1 & +7 & -3 & - & - & $\cdot$ & - & - & $\begin{array}{l}+3 \\
-2\end{array}$ & +3 & +1 & +2 & +5 & -1 & -5 & -1 & $\cdot$ & \\
\hline Aleg & 45 & 10 & 28 & 33 & 33 & 24 & 65 & 18 & 11 & 25 & 13 & 16 & 39 & 15 & 3 & 33 & 0 & 60 & 3 & 5 \\
\hline Rean & 0 & 19 & 3 & 0 & 6 & 6 & 4 & 93 & 56 & 30 & 4 & 14 & 0 & 1 & 8 & 9 & 5 & 11 & 1 & 0 \\
\hline ISP & 2.36 & -0.47 & 1.31 & 1.73 & 1.42 & 0.94 & 3.2 & -3.94 & -2.52 & -0.26 & 0.47 & 0.10 & 2.05 & 0.73 & -0.26 & 1.26 & -0.26 & 2.57 & 0.10 & 0.26 \\
\hline
\end{tabular}

Figure 1. Sociomatrix of the initial questionnaire

However, there is a child, AI, with 0 choices and 5 rejections, who is not a student of the school and is not known by the other children, so he is somehow marginalized. We have to mention that there are groups of 3-4 children from the same class and they have their own interconnections. Moreover, 2 children record a large number of rejections, $\mathrm{DA}=93$ and $\mathrm{SD}=56$, the former being very aggressive with other children physically as well as verbally, and the latter, showing little athletic ability, and therefore being seldom desirable in the team by the colleagues. Calculating the preferential status index by applying the ISP formula $=$ (ChoicesRejections) / $\mathrm{N}-1$, where $\mathrm{N}=$ total number of children, we have obtained the following results: ized";

- 6 children with a negative index, being therefore considered "the marginal-

- no child with an index 0 , therefore "the indifferent";

- 9 children between 0 and 1.5 index, falling into "the accepted";

- 5 children with an index above 1.5, being considered "the popular";

- out of these, 2 recorded preferential status index values above 2.5, a girl and respectively a boy, being not only agreed by the people in the group, but also very motor and appreciated by colleagues for their sports value. These two show characteristics of potential leaders, playing a key role in team building, as decision- making factors. 
Within the group there were 14 mutual choices and the group cohesion index has a value of 0.07 , calculated according to the following formula:

Icg $=\sum$ Mutual choices x 2 / N(N-2), where $\mathrm{N}=$ no. of children.

The results recorded in the final testing can be found in Fig 2. The second questionnaire was applied on June $5^{\text {th }}$, 2015, five months after the first, and during this period, namely in the 14 workouts, at least 3-4 collective drills were applied in each lesson, all under the game and competition form to motivate children.

Among the means applied we can enumerate: - pair games such as "Cocks" standing and squatting, "Mirror and I", "Touch my knees!”, "Touch my back!”, exercises with a stick for speed reaction development, exercises with a tennis ball for coordination skill building etc.; group games such as: "Net and fish", "10 team passes", "Fish and sharks", "Pairs' tag”, "Ducks and hunters in teams", "Steal fox tails!", "Defend the city", "Keep it clean" etc. As dosage, the exercises in pairs without objects being more intense, we conducted rounds of 2 minutes, 2-3 repetitions and 1-minute break. The team drills were applied for 5-7 minutes, 2 times every 1 minute break. After the application of the second questionnaire, the results show an improvement on the integration of children in the group and on the group cohesion itself.

\begin{tabular}{|c|c|c|c|c|c|c|c|c|c|c|c|c|c|c|c|c|c|c|c|c|}
\hline & SI & $\mathrm{RM}$ & $\mathrm{AO}$ & ED & $\mathrm{AC}$ & $\overline{M R}$ & RA & $\mathrm{DA}$ & DS & SD & $\mathrm{AC}$ & SD & RT & II & $\mathrm{RD}$ & AT & AI & MO & BM & 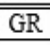 \\
\hline SI & & $\begin{array}{l}+5 \\
-3 \\
\end{array}$ & +7 & - & +2 & +2 & - & -3 & -1 & +2 & -2 & - & - & +1 & - & - & - & +8 & - & - \\
\hline RM & - & & - & +5 & - & - & +2 & +8 & - & +5 & - & +2 & - & - & - & +1 & - & -5 & - & - \\
\hline $\mathrm{AO}$ & +8 & -1 & & +2 & +3 & -2 & - & -2 & -3 & +2 & - & - & - & +5 & - & - & - & +5 & - & - \\
\hline ED & - & +2 & +1 & & - & - & +8 & +7 & +6 & - & - & - & +4 & - & - & - & - & - & - & - \\
\hline $\mathrm{AC}$ & +2 & - & - & - & & - & -2 & -5 & -5 & - & - & - & - & +7 & +1 & $\begin{array}{l}+2 \\
-2\end{array}$ & +3 & +9 & - & - \\
\hline $\mathbf{M R}$ & +3 & - & +2 & - & -3 & & - & $\begin{array}{l}-3 \\
\end{array}$ & - & -3 & +5 & -5 & - & +8 & - & - & +5 & - & - & - \\
\hline $\mathrm{RA}$ & - & +3 & - & +5 & - & - & - & -3 & +5 & - & - & - & +7 & - & - & - & -3 & +4 & - & -1 \\
\hline $\mathrm{DA}$ & - & +1 & - & +8 & - & - & +9 & & -6 & -2 & +3 & - & +3 & - & - & +3 & - & - & - & +2 \\
\hline DS & - & -3 & $\begin{array}{l}+4 \\
-3 \\
\end{array}$ & - & - & - & +8 & - & & - & - & - & +112 & - & - & - & - & - & +2 & - \\
\hline SD & - & $\begin{array}{l}+3 \\
-1\end{array}$ & - & - & - & - & -2 & +3 & -3 & & - & -3 & - & -2 & - & +10 & +2 & +3 & +1 & - \\
\hline $\mathrm{AC}$ & +3 & - & +10 & - & - & +3 & +4 & -5 & -2 & +2 & & - & - & - & -3 & - & - & +4 & +2 & - \\
\hline SD & +1 & +2 & - & - & +4 & +5 & - & $\begin{array}{l}+3 \\
-3\end{array}$ & - & +4 & +1 & & - & - & - & - & - & -2 & - & - \\
\hline RT & +5 & +2 & +2 & +3 & +3 & - & +8 & -5 & -5 & - & - & - & & - & - & - & +1 & +3 & - & - \\
\hline IL & +9 & - & - & - & - & +11 & - & -5 & - & -4 & - & -4 & - & & +1 & +2 & +1 & - & - & - \\
\hline $\mathrm{RD}$ & +3 & +2 & - & - & +6 & -4 & - & -6 & - & +11 & - & - & - & -1 & & - & - & +3 & - & +3 \\
\hline $\mathrm{AT}$ & +3 & -1 & +2 & - & +6 & +3 & +6 & -5 & -5 & -2 & - & - & - & +2 & - & & - & +4 & +2 & +3 \\
\hline AI & - & - & - & - & +7 & +1 & +4 & -3 & $\begin{array}{l}+2 \\
-3\end{array}$ & - & - & +5 & - & - & +2 & -2 & & +1 & -1 & - \\
\hline MO & - & - & - & +3 & +4 & - & +6 & $\begin{array}{l}+2 \\
-2\end{array}$ & -5 & +3 & - & +1 & +3 & -2 & -1 & +2 & +1 & & - & +1 \\
\hline $\mathrm{BM}$ & - & - & - & - & +7 & - & - & $\begin{array}{l}+3 \\
-2 \\
\end{array}$ & -2 & -1 & +3 & +6 & - & - & +2 & +2 & +3 & - & & - \\
\hline GR & - & -5 & +1 & +7 & -3 & - & - & - & - & - & $\begin{array}{l}+3 \\
-2\end{array}$ & +3 & +1 & +2 & +5 & -1 & +5 & -1 & - & \\
\hline Aleg & 37 & 20 & $2-9$ & 33 & 42 & 24 & 55 & 26 & 13 & 27 & 15 & 17 & 30 & 25 & 11 & 22 & 16 & 44 & 7 & 9 \\
\hline Resp & 0 & 14 & 3 & 0 & 6 & 6 & 4 & 49 & 40 & 12 & 4 & 12 & 0 & 5 & 4 & 4 & 8 & 8 & 1 & 1 \\
\hline ISP & 1.94 & 0.31 & 1.36 & 1.73 & 1.89 & 0.94 & 2.68 & -1.21 & -1.42 & 0.78 & 0.57 & 0.26 & 1.57 & 1.05 & 0.36 & 0.94 & 0.42 & 1.89 & 0.31 & 42 \\
\hline
\end{tabular}

Figure 2. Sociomatrix of the final questionnaire

Following the interpretation of the socio-matrix, we have found 3 children with 0 rejections, the same as in the first test (SI, ED, RT), except the last, GR, who 
obtained a rejection. Two children, DA and DS who had 95 and 56 rejections respectively, record 49 or 40 rejections this time, a sign of tolerance and acceptance of the group, but also of integration from them through positive behavioral changes. In addition to the applied collective games, we also discussed with the student DA, who had a totally inadequate behavior towards his colleagues.

By calculating the preferential status index, we obtained the following results: 2 children with a negative index, 4 fewer than at the first test, and having a better index than at the first test; no child with a zero index; 12 children with an index between 0 and 1.5, thus passing from the marginalized category of children into "the accepted"; 6 children are considered popular, one more than in the first questionnaire, the same two being on top of the list, MO as female and RA as male, but with a preferential status index lower by about 0.60 than at the first test because the positive points were also awarded to other colleagues at different questions not only to them. That is, if the two got even 12 points from one colleague to the second questionnaire, although remaining in the list of preferences, they were given fewer points, increasing instead the preferential status index to other children.

\section{Discussions}

We note that at both tests there were children who refused to answer to the negative questions. Within the group there were 18 mutual choices this time, 4 more than at the first evaluation, the group cohesion index increasing by 0.03 which underlines that 'teamwork fosters the manifestation of the players' individuality (FRH, 2014), favoring the integration of children within the group. Starting from the conclusion highlighted by Golu, (1971), namely the fact that "cohesion is regarded as the most important group variable since, because of it, the group exists, is maintained and functions as a coherent entity, relatively independent" (Golu, 1971, p. 87) and in this respect we believe that the first objective pursued in the activity was completed.

The horizontal relations among the group members become strengths in the training process for small athletes. This idea was highlighted by a study made by Cârstea (2017), who investigated the communication between the students in the classroom and the degree of group cohesion, because this "generates the emergence of an informal leader and of informal emotional relationships, determines the degree of integration or lack of integration of the group members, their likes and dislikes, attractions and rejections in the class, the breakout of various conflicts and the ways to solve them, involving teachers in solving the communication problems".

Following the received answers, the relationship with the coach is good, interactive the children appreciate that he "plays" with them, "helps" them, "is patient and explains", and to the last question targeting their need to be supported, most of them answered by referring to the execution technique of various technical elements such as rolling the ball, dribbling, throwing and catching a ball, elements which slow down during various games, resulting in a loss of points and games in 
which they are involved, the children's desire to win being very high.

\section{Conclusions}

Therefore, the results from the second test prove the efficiency of the collective means, those aimed not only at motor skill training and stimulation of the motor potential, but also at the socialization of children within the team, their interaction, creating new friends through communication and a good integration at the group level, in short, an increase of the group cohesion. The exercises in pairs and in teams had a positive effect, creating interpersonal relationships and connections between the group members, as evidenced by the results of the second sociomatrix. The hypothesis, according to which if we use in a 6-7-year-old group of children exercises for teaching handball, the level of social integration is improved, was confirmed. We can emphasize that the social objectives to integrate the children in a group was achieved, which underlines the need for group activities at this age.

\section{References}

1. BALINT, E. (2006). Instruirea copiilor și juniorilor în conţinutul jocului de handbal, Brașov: Universitatea "Transilvania”, 11;

2. BOTA, I., \& BOTA, M. (1990). Handbal-500 de exercitii pentru invatarea jocului, București: Sport Turism;

3. CĂRSTEA, A-M. (2017, January 1). Studiu privind gradul de coeziune al grupului scolar si implicatiile managerului clasei, https://abcdidactic.net/2014/02/27/Studiu privind gradul de coeziune al grupului scolar si implicatiile managerului clasei;

4. EPURAN, M., \& STANESCU, M. (2010). Învățarea motrică-aplicații în activitățile corporale, București: Discobolul 269;

5. F.R.H. (2014). http://www.dstmb.ro/wp-content/uploads/2014/02/ Orientarea Metodica a pregatirii in Handbal, 14_02_2014-final.pdf

6. GOLU, P. (1971). Psihologia sociala, București: Didactică și Pedagogică, 56;

7. HANTĂU, C. (2004). Handbal - Antrenamentul copiilor și juniorilor, București: Printech;

8. LUPU, G.S. (2012). Optimizarea relaţiilor psihosociale din cadrul echipelor de jocuri sportive în vederea creşterii capacităţii de performanţă, Bacău: Alma Mater, 295;

9. RIZESCU, C. (2017 a, January 1). Planificarea procesului de pregătire a începătorilor în handbal, doc. http:FRH;

10. RIZESCU, C. (2017 b, January 1). Planificarea procesului de pregătire a începătorilor în handbal, doc. http:FRH. 


\title{
Integrarea Socială a Copiilor de 6-7 Ani în Cadrul Unui Grup de Inițiere in Handbal
}

\author{
Sburlan Irina ${ }^{1}$ \\ Rață Gloria ${ }^{2}$ \\ ${ }^{1}$ UNEFS București, Strada Constantin Noica nr.140, 060057, Romania \\ 2Universitatea "Vasile Alecsandri" din Bacău, Calea Mărășești, 157, 600115, Romania
}

Cuvinte cheie: copii, grup, integrare, coeziune, mişcare

\section{Rezumat}

Studiul de faţă este unul de tip constatativ, şi vizează abordarea procesului de pregătire la copiii de 6-7 ani în jocul de handbal, din perspectiva socializării și are ca principal obiectiv crearea unor relaţii interpersonale în cadrul echipei între jucatori. Folosind studiul bibliografic, testul sociometric, analiza şi interpretarea datelor, culese de la 20 copii (10 fetiţe şi 10 băieţi de 6-7 ani), care au fost incluşi într-un program de pregătire, în care s-a urmărit realizarea grupului, am reuşit să validăm ipoteza conform căreia dacă folosim la un grup format din copii de 6-7 ani, exerciții pentru învățarea jocului de handbal nivelul de integrare socială se îmbunătățește. Concluzia evidenţiază faptul că rezultatele obtinute în urma celei de-a doua testări dovedesc eficienţa mijloacelor cu caracter colectiv.

\section{Introducere}

Comunicarea, socializarea, posibilitatea creării unor relații interpersonale sunt competenţe necesare oricarui individ, în vederea integrarii în societate. Educația fizică şi sportul reprezintă instrumente de bază în formarea acestor competențe, atât în rândul adulţilor cât şi al copiilor. Atitudinile, deprinderile, regulile asimilate în cadrul activităţilor sportive se pot transfera în orice altă sferă socială şi pot fi adaptate acesteia. In sporturile de echipă, crearea unor legături în cadrul grupului sunt absolut necesare în vederea eficientizării jocului. Acest lucru trebuie urmărit şi dezvoltat încă de la formarea grupelor de iniţiere, legarea unor prietenii, formarea unor interconexiuni în cadrul echipei, reflectandu-se în relaţiile de joc şi implicit în calitatea jocului în sine.

Activitatea de inițiere într-o disciplină sportivă este o activitate greoaie ce necesită o amuncă dificilă și responsabilă. Selecția este activă, continuă și prospectivă. Fiind un proces activ, dinamic și continuu selecția este "bidimensională" ea se desfășoară pe verticală și orizontală. "La copiii începători numai pe orizontală, antrenorul având obligația să observe, să cunoască aria de selecție și să verifice disponibilitățile pentru handbal și anume calitățile și capacitățile de integrare în colective. Selecția pe orizontală este activă cea pe verticală" urmărind promovarea fiind rară, exigentă și obiectivă” (Balint, 2006, p. 11).

Se știe că la fete și chiar la băieți capacitatea maximă de performanță se poate obține după vârsta de 20 ani astfel că durata unui ciclu de pregătire durează între 810 ani. Totodată "dorinţa specialiştilor de a efectua o eşalonare cât mai raţională a 
conţinutului instruirii, a metodelor şi mijloacelor de antrenament a condus la necesitatea periodizării și programării pregătirii sportivilor" (Bota \& Bota, 1990). Pe lângă modificările vizibile ale jocului de handbal, precum creșterea vitezei jocului și a caracteristicilor jucătorilor, există și dedesubturile științei antrenamentului sportiv care-și pun amprenta asupra evoluției sportului în timp. Astfel, o etapă de maximă importanță este selecția,"materialul" cu care se pornește lucrul. Vârsta selecției în ultima decadă a scăzut considerabil deoarece "vârsta școlarității este perioada optimă pentru observarea, învățarea, formarea și consolidarea deprinderilor motrice de bază și elementar sportive, necesare educării calităților motrice, fiind caracterizată prin cele mai mari progrese în ceea ce privește motricitatea” (Rizescu, 2017a). În privința formelor organizatorice, procesul de instruire în handbal se desfășoară în general în două forme "în unitățile școlare, în cadrul lecțiilor de educație fizică și în secțiile de handbal ale cluburilor și asociațiilor sportive” (Rizescu, 2017b).

Parcurgerea diverselor surse bibliografice ne permite să evidențiem că "vârsta de aur" cum este considerată vârsta școlară mică se caracterizează prin înregistrarea creșterilor în înălțime și greutate, dar și prin asimilarea de deprinderi motrice. "Deprinderea reprezintă rezultatul învățării, fiind o manieră de comportare care se formează prin exersare, caracterizată printr-o serie de trăsături specifice, dintre care cea mai importantă poate fi considerată sinteza realizată pe plan cognitiv, senzorial motric sau kinestezic” (Epuran \& Stanescu, 2010, p. 269).

Etapa pregătirii de bază, ca etapă a pregătirii dirijate se urmăreşte consolidarea deprinderilor și are ca linie directoare formarea "spiritului de echipă" (Hantău, 2004)” ca și condiție esențială în pregătirea sporturilor de echipă.

\section{Material și metode}

Studiul s-a realizat pe o grupă de handbal mixtă (10 fete si 10 baieti) eterogenă din punct de vedere etnic, alcatuită din copii de 6 si 7 ani, media de vârstă fiind 6,42 ani (abaterea standard 0,51 ani), aparținand Școlii Gimnaziale "Grigorie Ghica Voievod" din sectorul 2, București.

Copiii au fost selecționați aleator, de la clasele pregatitoare și întâi, la începutul anului școlar 2014-2015, antrenându-se din octombrie până în iunie 2015, de doua ori pe săptămână, luni și joi, 90 de minute. Principalele obiective de instruire la această categorie sunt de integrare a copiilor în grup, de formare a deprinderilor motrice de bază, utilitar aplicative și specifice, și de dezvoltare a calităţilor motrice, cu accent pe viteza și capacități coordinative, la care se adaugă formarea personalității.

Urmărind aceste obiective am verificat ipoteza conform căreia "dacă folosim la un grup format din copii de 6-7 ani, exerciții pentru învățarea jocului de handbal nivelul de integrare socială se îmbunătățește“.

In vederea atingerii obiectivelor sociale și de integrare, dar și pentru cunoașterea nivelului de coeziune a grupului, am utilizat ca metodă de cercetare metoda chestionarului, aplicând Testul Sociometric (preluat de la Colibaba-Evulet), pe 5 ianuarie 2015, la trei luni de zile după începerea antrenamentelor, tocmai 
pentru a oferi timp copiilor de a se cunoaște între ei și după 6 luni de zile.

Testul s-a desfășurat individual, în scris și a constat în aplicarea unui chestionar cu 11 întrebari referitoare la relația lor cu ceilalți copii din grup. S-a acordat $+/-3$ puncte primului ales, +/- 2 puncte celui de-al doilea și $+/-1$ punct ultimului ales. La întrebările cu un singur răspuns se acordă doar $+/-1$ punct. În urma colectării rezultatelor, s-a întocmit o sociomatrice și s-a calculat numărul de alegeri, respectiv de respingeri pentru fiecare copil, indicele de statut preferențial pentru fiecare și indicele de coeziune al grupului, urmând a se stabili după cea de-a doua aplicare a chestionarului, dacă exercițiile realizate au avut efectul scontat, de imbunătăţire a coeziunii grupului.

Ca materiale de lucru s-au folosit: mingi de handbal de dimensiuni reduse, mingi de tenis, bastoane, banci, scărița, jaloane, maieuri de departajare, scaune, gardulețe, saltele de gimnastică.

Testul Sociometric folosit de Lupu, în 2012 (test preluat de Colibaba-Evuleț) viza răspunsurile la următoarele întrebări: Care ar fi primii trei dintre colegii tăi cu care ai vrea să mergi într-o excursie?; Care ar fi cei trei colegi cu care nu ţi-ar plăcea sa mergi într-o excursie?; Care ar fi primii 3 colegi cu care ai vrea să joci pe teren la un meci important?; Care ar fi cei trei colegi cu care nu vrei să joci pe teren la un meci important?; Care este ordinea valorică a primilor 3 colegi (incluzându-te şi pe tine); Enumeraţi în ordine 3 parteneri cu care aţi dori să intraţi în echipă; Enumeraţi în ordine 3 parteneri cu care n-aţi dori să colaboraţi; Care dintre colegi crezi că te alege?; Pe cine ai conta în situaţii grele? (3 colegi); Care este cel mai bun partener din echipă/ din afara echipei; Cine îţi este indiferent?“ (Lupu, 2012, p. 295).

\section{Rezultate și discuții}

Rezultatele înregistrate în evaluarea inițială se regăsesc în Fig. 1. Datorită numărului mare de întrebări, există posibilitatea ca un copil să fie ales de mai multe ori în cadrul unui chestionar, motiv pentru care numărul punctelor din casuța unei matrice depășeste +/-3.

Observăm în urma interpretarii matricei că sunt 4 copii (SI, ED, RL, GR) cu 0 respingeri, 3 dintre aceștia fiind apreciați tocmai datorită comportamentului lor, fiind cuminți, atenți, receptivi și dând dovadă permanent de colegialitate. Cel de-al patrulea, datorită numărului mare de abstențe, nu este foarte bine cunoscut de ceilalți, motiv pentru care nu a primit nici o respingere, însă și numărul alegerilor este unul foarte redus de doar 5.

Există însă un copil, AI cu 0 alegeri și 5 respingeri, care nu este elev al școlii și nu este cunoscut de ceilalți copii, motiv pentru care este oarecum marginalizat. Menționez că există în echipa grupuri de 3-4 copii care provin din aceeași clasă și au propriile lor interconexiuni. De asemenea, 2 copii inregistrează un număr foarte mare de respingeri, $\mathrm{DA}=93$ si $\mathrm{DS}=56$, primul fiind foarte agresiv cu ceilalţi copii atăt fizic cît și verbal, iar cel de-al doilea, prezentând puține aptitudini sportive, și din acest motiv este rar dorit în echipă, de colegii săi.

Calculând indicele de statut preferenţial prin formula ISP $=($ AlegeriRespingeri) / $\mathrm{N}-1$, unde $\mathrm{N}=\mathrm{nr}$ total de copii, am obținut urmatoarele rezultate: 
- 6 copii cu indice negativ, fiind deci considerați "marginalizati";

- nici un copil cu indice 0, deci nici unul “ indiferent”;

- 9 copii cu indice între 0 si 1,5 , încadrându-se la categoria "acceptați”;

- 5 copii cu indice peste 1,5 fiind considerați la " populari“;

- dintre aceștia, 2 au inregistrat valori ale indicelui de statut preferențial de peste 2,5, o fată, respectiv un baiat, fiind nu doar agreați ca persoane în cadrul grupului, dar și foarte motrici și apreciați de ceilalți colegi pentru valoarea lor sportivă. Aceștia doi au caracteristici de potențiali lideri, jucând un rol esențial în constituirea echipei, ca factori de decizie. In cadrul grupului au fost 14 alegeri reciproce, iar indicele de coeziune al grupului are valoarea 0.07 , calculat in urma aplicarii formulei: Icg $=\sum$ Alegeri reciproce x $2 / \mathrm{N}(\mathrm{N}-2)$, unde $\mathrm{N}=$ nr.de copii.

\begin{tabular}{|c|c|c|c|c|c|c|c|c|c|c|c|c|c|c|c|c|c|c|c|c|}
\hline & SI & RM & $\mathrm{AO}$ & ED & $\mathrm{AC}$ & MR & $\mathrm{RA}$ & $\mathrm{DA}$ & DS & SD & $\mathrm{AC}$ & SD & RT & \begin{tabular}{|l|} 
II \\
\end{tabular} & $\mathrm{RD}$ & $\mathrm{AT}$ & AI & MO & BM & GR \\
\hline SI & & $+5-3$ & +7 & - & +2 & +2 & - & -3 & -1 & +2 & -2 & - & - & +1 & - & - & - & +8 & - & \begin{tabular}{|l} 
\\
\end{tabular} \\
\hline RM & - & & - & +5 & - & - & +2 & +8 & - & +5 & - & +2 & - & - & - & +1 & - & \begin{tabular}{|l|} 
\\
\end{tabular} & - & - \\
\hline A0 & +8 & -1 & & +2 & +3 & -2 & - & -2 & -3 & +2 & - & - & - & +5 & - & - & - & +5 & - & $\cdot$ \\
\hline ED & - & +2 & +1 & & - & - & +8 & +7 & +6 & - & - & - & +4 & - & - & - & - & - & - & - \\
\hline $\mathrm{AC}$ & +2 & - & - & - & & - & -2 & -5 & -5 & - & - & - & - & +7 & +1 & \begin{tabular}{|l|}
-2 \\
+2 \\
\end{tabular} & +3 & +9 & - & - \\
\hline MR & +3 & - & +2 & - & -3 & & - & -3 & - & -3 & +5 & -5 & - & +8 & - & - & +5 & - & - & - \\
\hline RA & - & +3 & - & +5 & - & - & & -3 & +5 & - & - & - & +7 & - & - & - & -3 & +4 & - & -1 \\
\hline $\mathrm{DA}$ & - & +1 & - & +8 & - & - & +9 & & -6 & -2 & +3 & - & +1 & - & - & +3 & - & - & - & +2 \\
\hline DS & - & -3 & - & - & - & - & +8 & - & & - & - & - & +12 & - & - & - & - & - & +2 & - \\
\hline SD & $\cdot$ & $\begin{array}{l}+3 \\
-1\end{array}$ & $\begin{array}{l}+4 \\
-3\end{array}$ & - & - & - & -2 & +3 & -3 & & - & -3 & - & -2 & - & +10 & +2 & +3 & +1 & $\cdot$ \\
\hline $\mathrm{AC}$ & +3 & - & - & - & - & +3 & +4 & -5 & -2 & +2 & & - & - & - & -3 & - & - & +4 & +2 & $\cdot$ \\
\hline SD & +1 & +2 & +10 & - & +4 & +5 & - & $\begin{array}{l}+3 \\
-3\end{array}$ & - & +4 & +1 & & - & - & - & - & - & -2 & - & - \\
\hline RT & +5 & +2 & - & +3 & +3 & - & +8 & -5 & .5 & - & - & - & 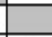 & - & - & - & +1 & +3 & - & - \\
\hline II & +9 & - & +2 & - & - & +11 & - & -5 & - & \begin{tabular}{|l|}
-4 \\
\end{tabular} & - & -4 & - & & +1 & +2 & +1 & - & - & - \\
\hline $\mathrm{RD}$ & +3 & +2 & - & - & +6 & -4 & - & -6 & - & +11 & - & - & - & - & & - & - & +3 & - & +2 \\
\hline AT & +3 & -1 & - & - & +6 & +3 & +6 & -5 & -5 & \begin{tabular}{|l|}
-2 \\
\end{tabular} & - & - & - & +2 & - & & - & +4 & +2 & +3 \\
\hline AI & - & - & +2 & - & +7 & +1 & +4 & -3 & $\begin{array}{l}+2 \\
-3 \\
\end{array}$ & - & - & +5 & - & - & +1 & -2 & & +1 & -1 & - \\
\hline MO & - & - & - & +3 & +4 & - & +6 & $\begin{array}{l}+2 \\
-2 \\
\end{array}$ & -5 & +3 & - & +1 & +3 & -2 & -1 & +2 & +1 & & - & +1 \\
\hline BM & - & - & - & - & +9 & - & - & $\begin{array}{l}+3 \\
-2 \\
\end{array}$ & -2 & -1 & +3 & +6 & - & - & +2 & +2 & +3 & - & & $\cdot$ \\
\hline GR & $\cdot$ & -5 & +1 & +7 & -3 & - & - & - & $\cdot$ & $\cdot$ & $\begin{array}{l}+3 \\
-2\end{array}$ & +3 & +1 & +2 & +5 & -1 & -5 & -1 & - & \\
\hline Aleg & 45 & 10 & 28 & 33 & 33 & 24 & 65 & 18 & 11 & 25 & 13 & 16 & 39 & 15 & 3 & 33 & 0 & 60 & 3 & 5 \\
\hline Reas & 0 & 19 & 3 & 0 & 6 & 6 & 4 & 93 & 56 & 30 & \begin{tabular}{|l|}
4 \\
\end{tabular} & 14 & 0 & 1 & 8 & 9 & \begin{tabular}{|l|}
5 \\
\end{tabular} & 11 & 1 & 0 \\
\hline ISP & 2.36 & -0.47 & 1.31 & 1.73 & 1.42 & 0.94 & 3.2 & -3.94 & -2.52 & -0.26 & 0.47 & 0.10 & 2.05 & 0.73 & -0.26 & 1.26 & -0.26 & 2.57 & 0.10 & 0.26 \\
\hline
\end{tabular}

Figura 1. Sociomatricea chestionarului initial

Rezultatele înregistrate în testarea finală se regăsesc în Fig. 2. Cel de-al doilea chestionar s-a aplicat pe 5 iunie 2015, la cinci luni de la primul, și în această perioadă, respectiv în cele 14 antrenamente, s-au aplicat cel putin 3-4 exerciții cu caracter colectiv în fiecare lecție, totul sub forma ludica și competiționala în vederea motivării copiilor.

Printre mijloacele aplicate se regăsesc: jocuri în pereche precum: «Cocoșeii» din picioare și din ghemuit, «Eu și oglinda«, «Atinge-mi genunchii!«, «Atinge-mă pe spate ! «, exerciții cu bastonul pentru dezvoltarea vitezei de reacție, exerciții cu mingea de tenis pentru dezvoltarea capacităților coordinative etc.; jocuri de grup: »Plasa 
si peștii», «10 pase în echipa«, «Peștii și rechinii«, «Leapșa pe perechi«, « Rațele și vânatorii pe echipe«, «Fură cozile de vulpe !«, «Apară cetatea«, «Menține locul curat« etc. Ca dozare, exercițiile în perechi fară obiecte, fiind mai intense, am desfășurat reprize de 2 minute, câte 2-3 repetări cu 1 minut pauză între ele. Cele pe echipa s-au aplicat în reprize de 5-7 minute de 2 ori fiecare cu 1 minut pauză între ele. După aplicarea celui de-al doilea chestionar, rezultatele dovedesc o îmbunătătire cu privire la integrarea copiilor în grup și la coeziunea grupului în sine.

Regăsim în urma interpretării sociomatricei, 3 copii cu 0 respingeri, aceeași ca la prima testare, (SI, ED, RT), excepție facând ultimul, GR care a obţinut o respingere. Cei doi copii, DA si DS care au avut 95, respectiv 56 de respingeri, înregistreaza de această dată 49, respectiv 40 de respingeri, semn de toleranță și acceptare din partea grupului, dar și de integrare din partea acestora prin modificari comportamentale pozitive. Pe lângă jocurile colective aplicate, am purtat și discutții cu elevul DA, care avea un comportament total neadecvat vis-a-vis de colegi.

\begin{tabular}{|c|c|c|c|c|c|c|c|c|c|c|c|c|c|c|c|c|c|c|c|c|}
\hline & SI & $\mathrm{RM}$ & $\mathrm{AO}$ & $E D$ & $\mathrm{AC}$ & $\mathbb{M R}$ & $\mathrm{RA}$ & $\mathrm{DA}$ & DS & SD & $\mathrm{AC}$ & SD & RT & II & $\mathrm{RD}$ & AT & AI & MO & BM & GR \\
\hline SI & & $\begin{array}{l}+5 \\
-3\end{array}$ & +7 & - & +2 & +2 & - & -3 & -1 & +2 & -2 & - & - & +1 & - & - & - & +8 & - & - \\
\hline RM & - & & - & +5 & - & - & +2 & +8 & - & +5 & - & +2 & - & - & - & +1 & - & -5 & - & - \\
\hline AO & +8 & -1 & & +2 & +3 & -2 & - & -2 & -3 & +2 & - & - & - & +5 & - & - & - & +5 & - & - \\
\hline ED & - & +2 & +1 & & - & - & +8 & +7 & +6 & - & - & - & +4 & - & - & - & - & - & - & - \\
\hline $\mathrm{AC}$ & +2 & - & - & - & & - & -2 & -5 & -5 & - & - & - & - & +7 & +1 & $\begin{array}{l}+2 \\
-2\end{array}$ & +3 & +9 & - & $\cdot$ \\
\hline $\mathbf{M R}$ & +3 & - & +2 & - & -3 & 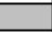 & - & -3 & - & -3 & +5 & -5 & - & +8 & - & - & +5 & - & - & - \\
\hline RA & - & +3 & - & +5 & - & - & - & -3 & +5 & - & - & - & +7 & - & - & - & -3 & +4 & - & -1 \\
\hline $\mathrm{DA}$ & - & +1 & - & +8 & - & - & +9 & & -6 & -2 & +3 & - & +3 & - & - & +3 & - & - & - & +2 \\
\hline DS & - & -3 & $\begin{array}{l}+4 \\
-3 \\
\end{array}$ & - & - & - & +8 & - & & - & - & - & +112 & - & - & - & - & - & +2 & $\cdot$ \\
\hline SD & - & $\begin{array}{l}+3 \\
-1\end{array}$ & - & - & - & - & -2 & +3 & -3 & & - & -3 & - & -2 & - & +10 & +2 & +3 & +1 & - \\
\hline $\mathrm{AC}$ & +3 & - & +10 & - & - & +3 & +4 & -5 & -2 & +2 & & - & - & - & $\begin{array}{l}-3 \\
\end{array}$ & - & - & +4 & +2 & - \\
\hline SD & +1 & +2 & - & - & +4 & +5 & - & $\begin{array}{l}+3 \\
-3\end{array}$ & - & +4 & +1 & & - & - & - & - & - & -2 & - & - \\
\hline RT & +5 & +2 & +2 & +3 & +3 & - & +8 & -5 & -5 & - & - & - & . & - & - & - & +1 & +3 & - & - \\
\hline II & +9 & - & - & - & - & +11 & - & -5 & - & -4 & - & -4 & - & & +1 & +2 & +1 & - & - & - \\
\hline $\mathrm{RD}$ & +3 & +2 & - & - & +6 & -4 & - & -6 & - & +11 & - & - & - & -1 & & - & - & +3 & - & +3 \\
\hline AT & +3 & -1 & +2 & - & +6 & +3 & +6 & -5 & -5 & -2 & - & - & - & +2 & - & & - & +4 & +2 & +3 \\
\hline AI & - & - & - & - & +7 & +1 & +4 & -3 & $\begin{array}{l}+2 \\
-3\end{array}$ & - & - & +5 & - & - & +2 & -2 & & +1 & -1 & - \\
\hline MO & - & - & - & +3 & +4 & - & +6 & $\begin{array}{l}+2 \\
-2\end{array}$ & -5 & +3 & - & +1 & +3 & -2 & -1 & +2 & +1 & & - & +1 \\
\hline $\mathrm{BM}$ & - & - & - & - & +7 & - & - & $\begin{array}{l}+3 \\
-2\end{array}$ & -2 & -1 & +3 & +6 & - & - & +2 & +2 & +3 & - & & - \\
\hline GR & - & -5 & +1 & +7 & -3 & - & - & - & - & - & $\begin{array}{l}+3 \\
-2\end{array}$ & +3 & +1 & +2 & +5 & -1 & +5 & -1 & - & \\
\hline Aleg & 37 & 20 & $2-9$ & 33 & 42 & 24 & 55 & 26 & 13 & 27 & 15 & 17 & 30 & 25 & 11 & 22 & 16 & 44 & 7 & 9 \\
\hline Resp. & 0 & 14 & 3 & 0 & 6 & 6 & 4 & 49 & 40 & 12 & 4 & 12 & 0 & 5 & 4 & 4 & 8 & 8 & 1 & 1 \\
\hline ISP & 1.94 & 0.31 & 1.36 & 1.73 & 1.89 & 0.94 & 2.68 & -1.21 & -1.42 & 0.78 & 0.57 & 0.26 & 1.57 & 1.05 & 0.36 & 0.94 & 0.42 & 1.89 & 0.31 & 0.42 \\
\hline
\end{tabular}

Figura 2. Sociomatricea chestionarului final

Calculând indicele de statut preferențial, am obținut urmatoarele rezultate: 2 copii cu indice negative, cu 4 mai puțini ca la prima testare, și acestia având un indice mai bun față de prima testare; niciun copil cu indice $0 ; 12$ copii cu indice intre 0 si 1.5 , cei marginalizati trecand astfel la categoria copiilor «acceptati « de grup; 6 copii sunt considerați populari, cu unul mai mult faţă de primul chestionar, aceeași 2 fiind în topul listei, MO de sex feminin și RA de sex masculin, însă cu un indice de statut preferențial mai mic cu aproximativ 0.60 faţă de prima testare, deoarece punctele pozitive au fost atribuite și altor colegi la diferite întrebări nu 
doar acestora. Adică, dacă cei doi obțineau și 12 puncte de la un singur coleg, la cel de-al doilea chestionar, deși au rămas în lista preferințelor, acestora li s-au împărțit mai puține puncte, crescând în schimb altor copii indicele de statut preferențial.

\section{Discuții}

Menționăm ca la ambele testări, au și fost copii care au refuzat să raspundă la întrebările negative. În cadrul grupului au fost de această dată 18 alegeri reciproce, cu 4 mai multe decât la prima evaluare, indicele de coeziune al grupului crescând cu 0.03, aspect ce subliniază că "lucru în echipă favorizează manifestarea individualităţii jucătorilor" (F.R.H., 2014), favorizează integrarea copiilor în cadrul grupului.

Plecând de la concluzia evidențiată de Golu (1971), adică a faptului că o "coeziune este considerată drept cea mai importantă variabila de grup, deoarece tocmai datorită ei, grupul există, se menține, și funcționează ca o entitate coerentă, relativ de sine statatoare“(Golu, 1971, p. 87) și în acest sens putem considera că primul obiectiv urmărit în cadrul activității a fost îndeplinit.

Relaţiile pe orizontală stabilite între membrii grupului devin puncte forte în procesul de instruire al micilor sportivi. Această idee a fost evidențiată și printr-un studiu realizat de Cârstea, care a urmărit comunicarea elevilor în clasă şi gradul de coeziune a grupului, deoarece acesta "generează apariţia liderului informal şi a relaţiilor informal - afective, determină gradul de integrare sau de neintegrare a membrilor grupului, simpatiile şi antipatiile, atracţiile şi respingerile din clasă, apariţia diferitelor conflicte şi modalităţile de a le rezolva, implicarea cadrelor didactice în rezolvarea unor probleme de comunicare“ (Cârstea, 2017).

În urma răspunsurilor primite, relația cu antrenorul este una bună, interactivă, copiii îl apreciază pentru ca "se joacă" cu ei, "îi ajută", "are răbdare și le explică", iar la cea din urmă întrebare vizand nevoia acestora de a fi sprijiniti, majoritatea au raspuns facand referire la tehnica executiei diferitelor elemente tehnice precum rularea mingii, dribling, aruncarea și prinderea mingii, elemente care le încetinesc viteza în timpul diverselor jocuri, ducând la pierderea punctelor și jocurilor în care sunt implicați, dorința de a câștiga a copiilor fiind foarte mare.

\section{Concluzii}

Drept urmare, rezultatele obtinute în urma celei de-a doua testari dovedesc eficiența mijloacelor cu caracter colectiv, cele care urmaresc nu doar formarea deprinderilor motrice și stimularea potențialului motric, ci și socializarea copiilor în cadrul echipei, interacțiunea dintre aceștia, crearea de noi prieteni prin comunicare și, buna integrare la nivelul grupului, pe scurt, creșterea coeziunii grupului. Exercițiile pe perechi și în echipe au avut un efect pozitiv, creând relații interpersonale și conexiuni între membrii grupului, fapt dovedit prin rezultatele celei de-a doua sociomatrice. Ipoteza conform căreia "dacă folosim la un grup format din copii de 6-7 ani, exerciții pentru învățarea jocului de handbal nivelul de integrare socială se imbunătățește“ s-a confirmat. Putem sublinia faptul că obiectivele sociale de integrare a copiilor într-un grup s-a realizat, aspect ce subliniază necesitatea activităților de grup la această vârstă. 